\title{
NUTRITIONAL AND MEDICAL PROPERTIES OF MARE'S MILK (review)
}

\section{AT MUSAEV, BS ZHUSSUPOV, ZM ZHANEN, BOMMAGANI SAI CHANDANA, ZhY MERGENBAYEV, MACHERLA SAI CHARAN, PEDDINTI VENKATA MANOJ KUMAR, DG SYZDYKBAYEVA \\ National Medical University, Almaty c., Republic of Kazakhstan}

Recent interest in mare's milk is associated with the fact that it was used by many people around the world, is an ancient relic of Turkic people and contains a wide variety of nutrients with health-promoting properties. Among milk of many mammal species, mare's milk is highly appreciated for similarity to human milk in terms of chemical composition allowing its use as a substitute for mother's milk in infant feeding. It can also be used in feeding people with various health conditions, particularly the patients in group of risk or suffering from Tuberculosis and Hepatitis $\mathrm{C}$. This article is making a review of rich composition of mare's milk.

Keywords: mare's milk, composition, fats, proteins, carbohydrates, vitamins.

For references: Musaev AT, Zhussupov BS, Zhanen ZM, Bommagani Sai Chandana, Mergenbayev ZhY, Macherla Sai Charan, Peddinti Venkata Manoj Kumar, Syzdykbayeva DG. Nutritional and medical properties of mare's milk (review). Meditsina (Almaty) = Medicine (Almaty). 2018;11(197):83-87 (In Russ.). DOI: 10.31082/1728-452X-2018-197-11-83-87

т¥жы Ры М

БИЕ СҮТІНІҢ ҚОРЕКТІК ЖӘНЕ ЕМДІК ҚАСИЕТTЕРІ (әдеби шолу)

А.Т. МУСАЕВ, Б.С. ЖУСУПОВ, З.М. ЖАНЕН, БОММАГАНИ САЙ ЧАНДАНА, Ж.Е. МЕРГЕНБАЕВ, МАЧЕРЛА САЙ ЧАРАН, ПЕДДИНТИ ВЕНКАТА МАНОЖ КУМАР, Д.Г. СЫЗДЫҚБАЕВА

«Ұлттық медицина университеті» АҚ, Алматы қ., Қазақстан Республикасы

Бие сүтіне деген соңғы қызығушылық оның әлемнің барлық халықтарымен қолданылып, сонымен қатар түркі халықтарының ежелгі байлығы болып табылатындықтан және пайдалы қасиеттері бар қоректік заттары мол сусын екенімен анықталады. Көптеген сүтқоректілердің ішінде бие сүтін оның ана сүтіне ұқсастығы үшін бағалайды, өз кезегінде бұл қасиет оны ана сүтін алмастырғыш ретінде пайдалануға мүмкіндік береді. Сондай-ақ, ол әр түрлі денсаулық мәселелері бар адамдарда, әсіресе туберкулезбен, С гепатитімен және әр түрлі иммунды тапшылығымен ауру қаупі бар науқастарда қолданылады. Мақалада бие сүтінің құрамы кеңінен келтірілген.

Негізгі сөздер: бие сүті, құрамы, белоктар, майлар, көмірсулар, дәрумендер.

Contacts: Abdugani T Musaev, Doctor of Medical Sciences, Professor of Department of Emergency and Emergency Medical Aid, National

Medical University, Almaty c., Tole bi str., 88 index 050000

E-mail: musaev.dr@mail.ru

Контакты: Мусаев Абдугани Таджибаевич, д-р мед. наук, профессор кафедры СНМП АО «Национальный

медицинский университет»,

г. Алматы, ул. Толе би, 88

индекс 050000.

E-mail: musaev.dr@mail.ru

Поступила 20.10.2018.

\section{P E 3 Ю M E}

ПИТАТЕЛЬНЫЕ И ЛЕЧЕБНЫЕ СВОЙСТВА КОБЫЛЬЕГО МОЛОКА (ОбЗОр)

А.Т. МУСАЕВ, Б.С. ЖУСУПОВ, З.М. ЖАНЕН, БОММАГАНИ САЙ ЧАНДАНА, Ж.Е. МЕРГЕНБАЕВ, МАЧЕРЛА САЙ ЧАРАН, ПЕДДИНТИ ВЕНКАТА МАНОЖ КУМАР, Д.Г. СЫЗДЫКБАЕВА

AO «Национальный медицинский университет», г. Алматы, Республика Казахстан

Недавний интерес к кобыльему молоку обусловлен тем, что оно употребляется всеми народами мира, а также является древней реликвией тюркских народов и содержит большое количество питательных веществ с полезными свойствами. Среди молока многих видов млекопитающих кобылье молоко высоко ценится за сходство с грудным молоком, позволяющее использовать его в качестве заменителя грудного молока. Оно также используется для питания людей с различными состояниями здоровья, в частности у пациентов в группе риска или страдающих туберкулезом, гепатитом C и различными видами иммунодефицита. В статье описывается богатый состав кобыльего молока.

Ключевые слова: кобылье молоко, состав, белки, жиры, углеводы, витамины.

Для цитирования: Мусаев А.Т., Жусупов Б.С., Жанен З.М., Боммагани Сай Чандана, Мергенбаев Ж.Е., Марчерла Сай Чаран, Педдинти Венката Манож Кумар, Сыздыкбаева Д.Г. Питательные и лечебные свойства кобыльего молока (обзор) // Медицина (Алматы). - 2018. - №11 (197). - С. 83-87
$\mathbf{M}$ are's milk is one of the most important drinking product for the human populations in those areas of central Asia, where a lactic alcoholic beverages called kumis and saumal are traditionally produced through fermentation [1].
Mare's milk is not like a cow's milk neither organoleptically nor by taste. It is clear, whitish, and sweeter than cow's milk, which makes it just like a human milk. Mare's milk differs greatly from milk of human or cow in terms of the key elements content. 
Fat

The fat content of mare's milk is considerably lower as compared with human and cow's milk (Figure 1). The quantitative relation of unsaturated-to-saturated fatty acids in mare's milk (1:3) is near to that in human milk (1:2), whereas it deviates from the values typical for cow's milk (2:1). Mare's milk is a good source of linoleic acid and $\alpha$-linolenic acid, which are not synthesized by the human body and which are essential for the growth and development of nervous system [4]. Mare's milk contains fewer triglycerides, but it is richer for free fatty acids (FFA) and phospholipids for 9 and 5 times respectively, which is necessary for cellular membranes. This way, it may save cell wall from oxidative phosphorylation.

\section{Proteins}

Mare's milk is similar to human milk in terms of protein composition, $8.30 \%$ and $7.60 \%$ respectively. Compared to other fractions (Figure 2), the percentage of whey protein in mare's milk is more than $20 \%$ higher than in cow's milk, amounting to approximately $40 \%$, but lower than in human milk (more than 50\%). Cow's milk has the highest amount of caseins. For that reason it is called casein type milk, whereas mare and human milk are called albumin type milk [2]. Due to the fact that cow milk contains big amount of caseins (coarse proteins), which induces allergy, infants develop allergy for it more often. On the other hand, mare's milk contains more albumins (finely dispersed), therefore it doesn't develop allergy.

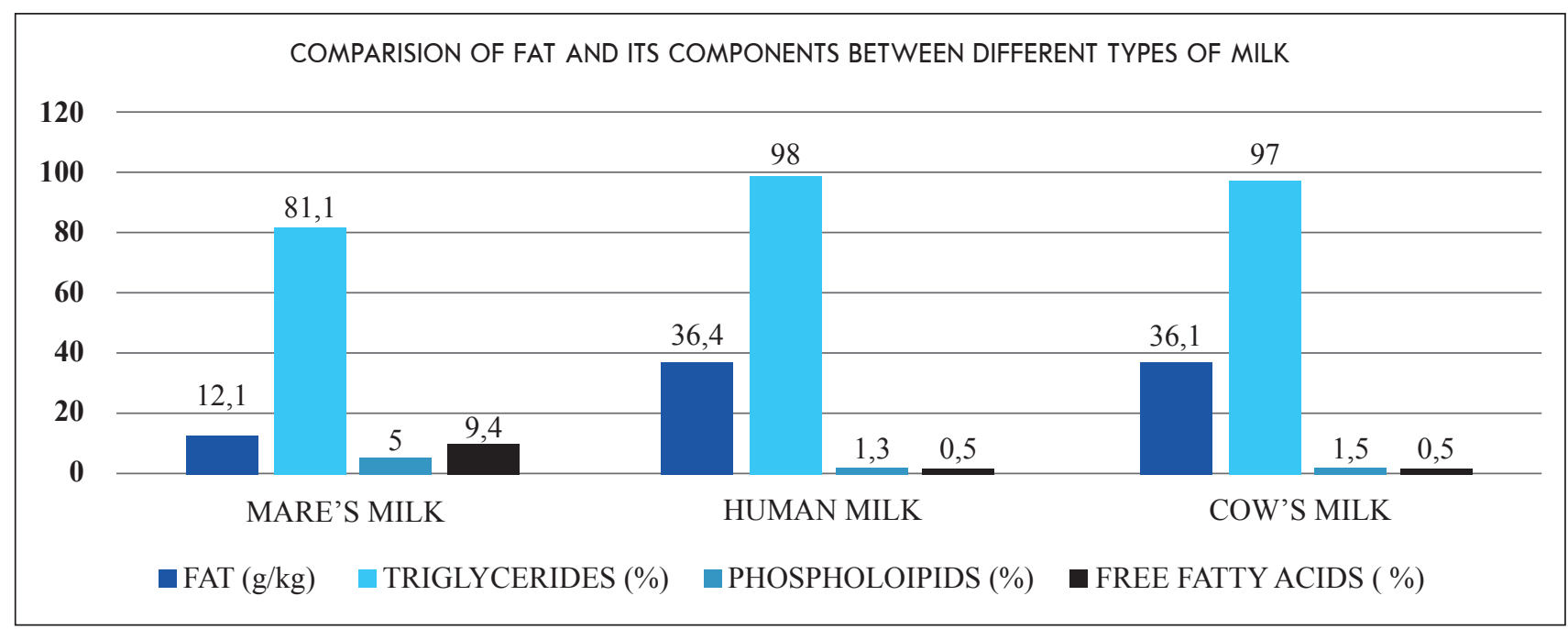

Figure 1 - Comparison of fat and it's components between different types of milk

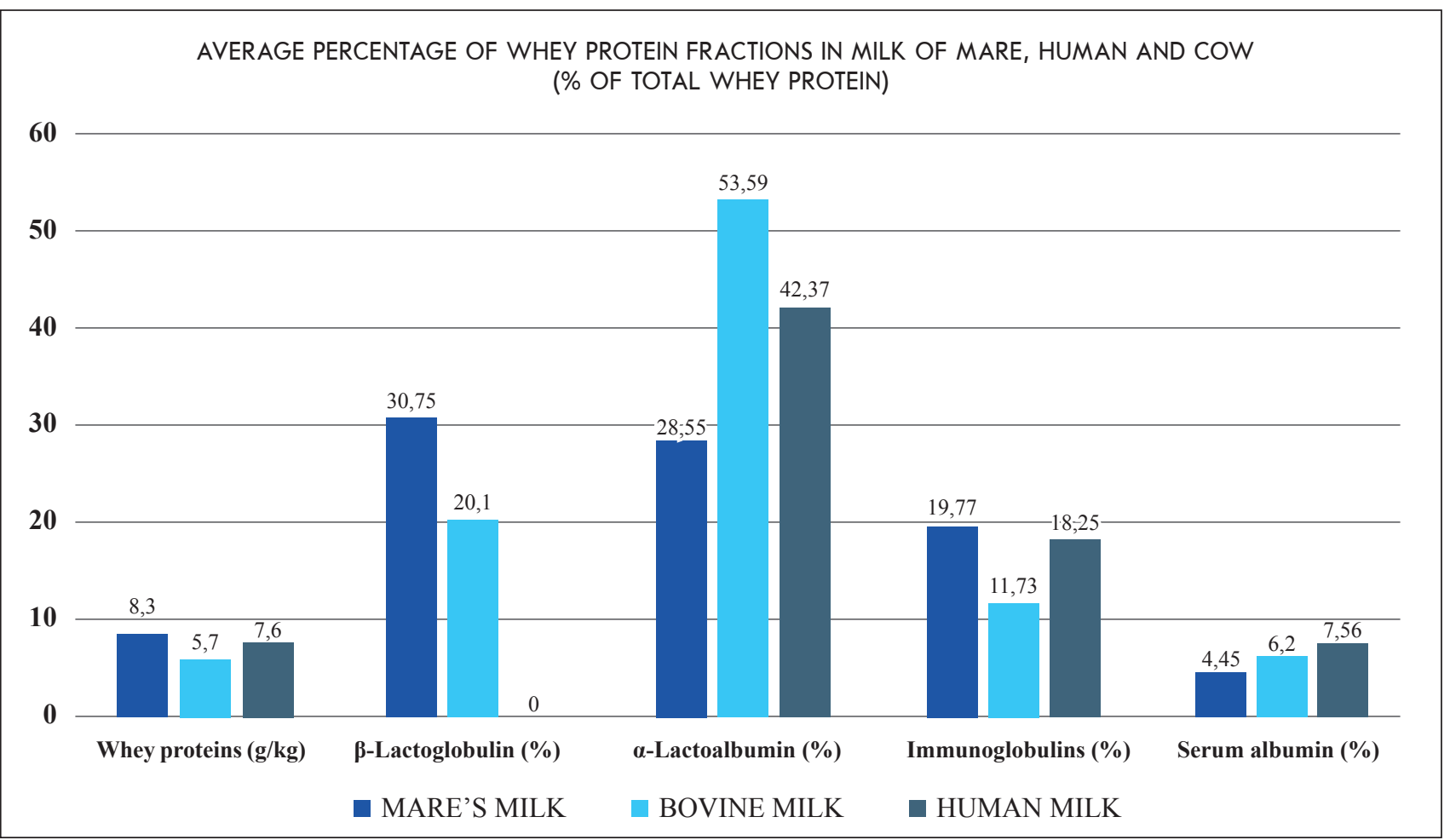

Figure 2 - Average percentage of whey protein fractions in milk of mare, human and cow (\% of total whey protein) 
The large amount of whey protein and exogenous amino acids in mare's milk make it a more beneficial source of nutrients for people than cow's milk [2].

Amino acids

Amino acids are important constituents of food. They supply the required building blocks for protein biosynthesis.

Due to a high percentage of whey proteins and exogenous amino acids, mare's milk is a better source of nutrients for humans than cow's milk [2] (Table 1).

The quantity of Asparagine, Threonine, Serotonin, Proline, Leucine and Lysine is almost 6 times higher in comparison with cow milk. On the other hand, Glutamine level is 3 times greater. But, however, human milk indexes are 10 times more in all points, which proves its' significance, for infant's muscular and skeletal system development. a symbiosis in which favorable microflora is created that compete with and exclude many potential pathogens [4].

Galactose, as a part of lactose, takes part in the myelination process and brain development in young organisms, which require significant amounts of galactosylceramides and galactolipids [7]. That's why milk galactose play a unique role in providing the requirements of the rapidly developing infant brain [5].

Vitamins

Mare's milk has been proven to contain vitamins A, D3, E, K2, C, B1, B2, B3, B6, B12. With the exception of vitamin C, the content of other vitamins in mare's and cow's milk does not differ significantly [7] (Table 2). Mare's milk is much richer in vitamin $\mathrm{C}$ as compared to cow's milk, and this vitamin has a high nutritional value due to its resistance to oxidation and anti-inflammatory properties. Mare's milk contains a similar

Table 1 - Comparison of essential and non-essential amino acids content $(\mathbf{g} / \mathbf{1 0 0} \mathrm{g}$ milk) in milk of mare, human and cow

\begin{tabular}{|c|c|c|c|}
\hline Amino acid & Mare's milk & Cow milk & Human milk \\
\hline \multicolumn{4}{|c|}{ Essential amino acids } \\
\hline His & 0.492 & 0.10 & 2.50 \\
\hline Ile & 0.492 & 0.14 & 6.09 \\
\hline Leu & 1.444 & 0.29 & 10.02 \\
\hline Lys & 1.444 & 0.27 & 6.33 \\
\hline Met & 0.213 & 0.06 & 2.94 \\
\hline Phe & 0.738 & 0.16 & 4.48 \\
\hline Thr & 1.132 & 0.15 & 4.22 \\
\hline Trp & 0.229 & 0.05 & - \\
\hline Val & 0.853 & 0.16 & 5.17 \\
\hline \multicolumn{4}{|c|}{ Non-essential amino acids } \\
\hline Asp & 1.543 & 0.26 & 9.85 \\
\hline Ser & 1.444 & 0.16 & 3.6 \\
\hline Glu & 2.281 & 0.77 & - \\
\hline Pro & 1.346 & 0.32 & - \\
\hline Gly & 0.558 & 0.06 & - \\
\hline Ala & 0.673 & 0.10 & 5.03 \\
\hline Cys & 0.164 & 0.02 & 0.99 \\
\hline lle & 0.492 & 0.14 & 6.09 \\
\hline Tyr & 0.771 & 0.15 & 4.19 \\
\hline Arg & 0.706 & 0.11 & 3.91 \\
\hline
\end{tabular}

Carbohydrates and lactose

Literature analysis showed that human milk contains a little bit more lactose $(6.71 \%)$ than mare's milk $(6.37 \%)$. It is the main source of carbohydrates. Lactose can be delivered to an organism only as a part of milk. As a constituent of milk, it can influence the process of seeding the gastrointestinal tract with microorganisms responsible for its breakdown. This results in level of vitamin A as compared to cow's milk but some authors [7] pointed out that it is less than in human milk. Results of recent studies showed that vitamin D was found in greater amount in mare's milk as compared to human milk [4]. According to [7], supplementation with vitamin D significantly decreased the risk of premature death and death from cancer as well as supporting general health. Mare's milk is characterized 
by an average concentration of vitamins from the B group, while human milk contains less and cow's milk more as compared to mare's milk (Table 2). The level of cobalamin was shown to be higher and vitamins B2 and B9 to be lower in mare's milk compared to human and cow's milk [10]. On the other hand, the level of Vitamin K is almost 9 times more compared with human milk, which means that it has a positive effect on blood coagulation system.
Table 3 - Comparison of minerals content $(\mathbf{m g} / \mathbf{1 0 0} \mathbf{~ m l ~ m i l k ) ~ i n ~ m i l k ~ o f ~ m a r e , ~}$ human and cow

\begin{tabular}{|c|c|c|c|}
\hline $\begin{array}{c}\text { Mineral } \\
\text { component }\end{array}$ & Mare's milk & Human milk & Cow milk \\
\hline $\mathrm{Ca} 2+$ & $50-135$ & $28-34$ & $112-123$ \\
\hline $\mathrm{P}+$ & $20-121$ & $14-43$ & $59-119$ \\
\hline $\mathrm{K}+$ & $25-87$ & $53-62$ & $106-163$ \\
\hline $\mathrm{Na}+$ & $8-85$ & $10-18$ & 58 \\
\hline $\mathrm{Cl}-$ & 19 & $60-63$ & $100-119$ \\
\hline
\end{tabular}

Table 2 - Comparison of fat soluble vitamins and watersoluble vitamins content in milk of mare, human, and cow

\begin{tabular}{|c|c|c|c|}
\hline Vitamins & Mare's milk & Human milk & Cow milk \\
\hline Vitamin A $(\mathrm{mg} / \mathrm{I})$ & 0.403 & 0.455 & $14-17$ \\
\hline Vitamin B1 $(\mu \mathrm{g} / \mathrm{I})$ & $20-40$ & $20-60$ & $115-202$ \\
\hline Vitamin B2 $(\mu \mathrm{g} / \mathrm{I})$ & $10-37$ & $147-178$ & $50-120$ \\
\hline Vitamin B3 $(\mu \mathrm{g} / \mathrm{I})$ & $70-140$ & $184-270$ & $260-490$ \\
\hline Vitamin B5 $(\mu \mathrm{g} / \mathrm{I})$ & $277-300$ & $11-14$ & $30-70$ \\
\hline Vitamin B6 $(\mu \mathrm{g} / \mathrm{I})$ & 30 & $5.2-16$ & $1-18$ \\
\hline Vitamin B9 $(\mu \mathrm{g} / \mathrm{I})$ & 0.13 & $0.03-0.05$ & 0.11 \\
\hline Vitamin B12 $(\mu \mathrm{g} / \mathrm{I})$ & 0.3 & $3500-10000$ & $300-2300$ \\
\hline Vitamin C $(\mu \mathrm{g} / \mathrm{I})$ & $1280-8100$ & $0.03-0.12$ & $2.31-15.39$ \\
\hline Vitamin D3 $(\mu \mathrm{g} / \mathrm{l})$ & 4.93 & 5.09 & $1.05-1.95$ \\
\hline Vitamin E $(\mathrm{mg} / \mathrm{l})$ & 1.13 & 1.8 & $4.81-17$ \\
\hline Vitamin K2 $(\mu \mathrm{g} / \mathrm{l})$ & 17.93 & & \\
\hline
\end{tabular}

\section{Minerals}

Mare's milk contains relatively few minerals $(0.5 \%)$ compared to cow's milk (0.8\%) (Table 6) [7]. However, its calcium-to-phosphorus ratio (1.6-1.8:1) is more favorable to the proper growth of the skeleton of young organisms than cow's milk (approximately 1.4:1) and is closer to that in human milk (approximately 1.9:1) [7].

Sodium in the form of cations plays an important role as a constituent of blood and extracellular fluid, potassium as a cation takes part in maintaining the integrity of intracellular fluid. Milk is generally a good source of calcium and phosphorus which are necessary for the process of bone growth and development, and also magnesium, which is needed for mineralization of bones [7].

There are major differences in the mineral content of mare's, cow's and human milk: the concentration of most minerals is higher in mare's milk than in human milk but much lower than in cow's milk (Table 3). The investigation showed that cow's milk contains about $50 \%$ more non-ionized $\mathrm{Ca}^{2+}$ and nearly twice as much $\mathrm{P}^{+}$and $\mathrm{K}^{+}$than mare's milk but horse milk contains about 2 times more ionized $\mathrm{Ca}^{2+}$ and $\mathrm{P}^{+}$than human milk [10]. $\mathrm{Ca}^{2+}$ to $\mathrm{P}^{+}$ratio of human and mare's milk are report- ed to be more favorable for intake of $\mathrm{Ca}^{2+}$ compared to the ratio in cow's milk, because it is ionized, which means is not connected with proteins. However, microelements concentration is low in all milks discussed.

Enzymes and hormones

Analysis of literature showed that beside valuable nutrients it also contains some enzymes and health promoting hormones.

Lysozyme

Also called N-acetylmuramidase, lysozyme is a hydrolyse-type enzyme that catalyses the breakdown of peptidoglycan polymers of bacterial cell wall at the 1-4 bond between $\mathrm{N}$-acetylmuramic acid and $\mathrm{N}$-acetylglucosamine residues, thereby lysing sensitive bacteria [6].

Antibacterial activity of lysozyme is essentially directed towards gram-positive bacteria, as their target cell-wall component (peptidoglycan) is freely accessible to the enzyme, compared to that of gram-negative bacteria, which is covered by the lipopolysaccharidic layer of the outer membrane [3]. In addition to bacteria, lysozyme has also been reported to inhibit viruses (HIV) and eukaryotic micro-organisms including parasites (Entamoeba histolytica trophozoites) and fungi (Can- 
dida albicans) despite the absence of typical peptidoglycan in their envelopes [3,6].

This way mare's milk is considered as not only perfect thirst quenching, but also as antibacterial drink. Therefore, nowadays it is used in treatment therapy against Tuberculosis.

Insulin and Insulin-like Growth Factor I

According to literature analysis, it was discovered that mare's colostrum contains a high amount of immunoreactive insulin (iI) and immunoreactive insulinlike growth factor I (iIGF-I). IGFs and insulin, in addition to their growth-promoting actions, are considered to play valuable role in the maintenance and development of normal cell functions throughout life. Theoretically, in near future it may be used as a supportive therapy in Diabetes Mellitus patients.

Leptin

Another hormone identified in mare's milk is a leptin. It can serve as an adiposity signal to inform the brain of the adipose tissue mass in a negative feedback loop regulating food intake and energy expenditure. Leptin also plays important roles in angiogenesis, immune function, fertility, and bone formation [8].

\section{CONCLUSION}

Mare's milk has long been a popular gourmet food with an exceptionally delicious flavor and subtle nuances found in no ordinary dairy product in Central Asia. On the basis of literature data analysis and review findings, it was found that it is not only

\section{REFERENCES}

1 Aitbayeva SE, Bimbetov BR. Mare's mil in children nutrition. Meditsina (Almaty) $=$ Medicine (Almaty). 2017 (In Russ.)

2 Csapo J, Csapo Kiss Z, Salamon S, Loki K. Composition of mare's colostrum and milk II. Protein content, amino acid composition and contents of macro- and micro-elements. Acta Universitatis Sapientiae, Alimentaria. 2009;2:133-48

3 El Agamy, Ruppanner R, Ismail A, Champagne CP, Assaf R. Antibacterial and antiviral activity of camel milk protective proteins. Journal of Dairy Research. 1992;59:169-75

4 Jastrzębska E, Wadas E, Daszkiewicz T, Pietrzak-Fiećko R. Nutritional value and health-promoting properties of mare's milk - a review. Czech Journal of Animal Sciences. 2017;62:511-8

5 Karimiova G, Gorbatovskaya N. Study of physico-chemical properties of fermented mare's milk to develop kas medi- food product and thirst quenching but also provides valuable nutrients for human body and has got treatment features due to its enzymes and hormones present in it. It is rich in proteins and carbohydrates, but it is low in fat, which makes it a dietary product. Due to the high percentage of whey proteins and exogenous amino acids, mare's milk is the best source of nutrients compared to cow's milk. And its high content of vitamin C confirms its importance and value in immunomodulation. A high concentration and optimal ratio of $\mathrm{Ca} 2+$ and $\mathrm{P}+$ in mare's milk was also detected. Data analysis showed that it also contains enzymes and hormones such as lysozyme, aminotransferases, insulin and insulin-like growth factor I, prolactin binding proteins and leptin. All medical and pharmacological aspects of mare's milk composition were discussed. However, discovering another features and its effectiveness in treatment of other diseases is in future perspective.

\section{Research transparency}

Research did not have a sponsorship. The authors are absolutely responsible for presenting the release script for publication.

\section{Declaration about financial and other relations}

All authors took part in elaboration of article conception and writing the script. The release script was approved by all authors. The authors did not get the honorary for the article.

\section{Conflict of interest}

The authors declare no conflict of interest.

cated products for children. Integration of Science \& Education. 2014;9:67-75

6 Masschalck B, Michiels CW. Antimicrobial properties of lysozyme in relation to foodborne vegetative bacteria. Critical Reviews in Microbiology. 2003;29:191-214

7 Pieszka M, Kulisa M. Magnesium content in mares' milk and growth parameters in their foal. Journal of Elementology. 2009;10:985-90

8 Potocnik K, Gantner V, Kuterovac K, Cividini A. Mare's milk: composition and protein fraction in comparison with different milk species. Mljekarstvo. 2011;61:107-13

9 Susana AG, Sigifredo AG. Quintín R.C. Lactoferrin: structure, function and applications. International Journal of Antimicrobial Agents. 2009;33:301-1, 301-8

10 Sheng Q, Fang X. Bioactive components in Mare milk. HongKong, 2009. P. 195 